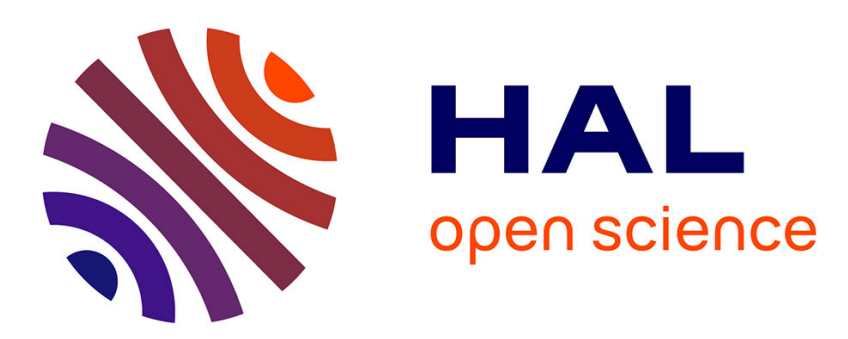

\title{
How does legislative behavior change when the country becomes democratic? The case of South Korea
}

\author{
F. Lagona, Fabio Padovano
}

\section{To cite this version:}

F. Lagona, Fabio Padovano. How does legislative behavior change when the country becomes democratic? The case of South Korea. European Journal of Political Economy, 2021, 69, pp.102026. 10.1016/j.ejpoleco.2021.102026 . hal-03225568

\section{HAL Id: hal-03225568 \\ https://hal.science/hal-03225568}

Submitted on 14 Oct 2021

HAL is a multi-disciplinary open access archive for the deposit and dissemination of scientific research documents, whether they are published or not. The documents may come from teaching and research institutions in France or abroad, or from public or private research centers.
L'archive ouverte pluridisciplinaire HAL, est destinée au dépôt et à la diffusion de documents scientifiques de niveau recherche, publiés ou non, émanant des établissements d'enseignement et de recherche français ou étrangers, des laboratoires publics ou privés. 


\section{HIGHLIGHTS}

- Test of the political legislation cycle in a country evolving from a dictatorship to a democracy

- First test of the political legislation cycle in an Asian sample

- Link between literatures on political legislation cycles and conditional political cycles

- Hurdle model discriminates between periods of legislative inactivity and production 
HOW DOES LEGISLATIVE BEHAVIOR CHANGE WHEN THE COUNTRY BECOMES DEMOCRATIC? THE CASE OF SOUTH KOREA

by

FRANCESCO LAGONA,

Dept. of Mathematics, University of Bergen, Allégaten 41, Bergen, Vestland 5007 Norway and Department of Political Sciences, University of Roma Tre, Via G. Chiabrera 199, 00145 Rome, Italy

email: francesco.lagona@uniroma3.it

and

\section{FABIO PADOVANO *}

* Corresponding author

University of Rennes 1, CNRS, CREM - UMR 6211, Condorcet Center for Political

Economy, F-35000 Rennes, France

and Department of Political Sciences, University of Roma Tre, Via G. Chiabrera 199, 00145

Rome, Italy

email: fabio.padovano@uniroma3.it 


\title{
HOW DOES LEGISLATIVE BEHAVIOR CHANGE WHEN THE COUNTRY BECOMES DEMOCRATIC? THE CASE OF SOUTH KOREA ${ }^{1}$
}

\begin{abstract}
The Political Legislation Cycle theory predicts a peak of legislative production in the preelectoral period, when legislators focus on voters' welfare to be reelected. This paper verifies the theory on South Korean legislative production (1948-2016) and it is the first test of the theory in a country undergoing a process of democratization, thus providing evidence relevant also for the conditional political cycles literature. Two insofar untested hypotheses are verified: 1) peaks of legislative production should increase with the degree of democracy; 2) as the party system and the mechanisms of legislative checks and balances develop, the PLC should become more evident in bills of legislative rather than executive's initiative. A hurdle model estimated on both laws of parliamentary proposal and of government assignment lends empirical support to both hypotheses, with the noticeable feature that PLC in Korea appear more in the form of an upward trend than of pre-electoral peaks.
\end{abstract}

Keywords: Political legislation cycles, conditional political cycles, democratic transition, autocracy, executive vs. parliamentary legislative initiative, hurdle model, zero inflation, over-dispersion

JEL classification codes: D72, C49, H61, H62

${ }^{1}$ Paper presented to the 2019 PCS and EPCS conferences and to the lunch seminar of the Department of Political Sciences of the University Roma Tre. We would like to thank Seonge Chun for excellent research assistance and translation services. The usual caveats apply.

\section{Accepted manuscript}




\section{Introduction}

This paper has two research aims: the first is connecting two similar, yet so far separated strands of literature, that on political legislation cycles and the one on conditional political cycles; the second is providing innovation to both of them.

The political legislation cycles (henceforth, PLC) theory (Lagona and Padovano, 2008; Padovano, 2017) predicts higher levels of legislative production in the pre-electoral period, when legislators focus on voters' welfare to be reelected. The conditional political cycles theory (Akhmedov and Zhuravaskaya, 2004; de Haan and Klomp, 2013; Aidt and Mooney, 2014; Shi and Svensson, 2006), on the other hand, posits that the size and nature of (usually budgetary) cycles are conditional on the political and institutional framework where policy decisions are taken. The analysis of the legislative cycle of the Republic of South Korea is relevant for both strands of literature, because it verifies not only whether a legislative cycle exists, as usual in the PLC literature, but also how it evolves as the politico-institutional environment surrounding the legislative production becomes more democratic - a typical subject matter of the conditional cycle models.

This paper also provides some innovations to both strands of literature. The PLC theory has received a substantial amount of supportive empirical tests, in a wide variety of institutional contexts: parliamentary systems like Italy (Lagona and Padovano, 2008; Lagona et al., 2015), presidential systems such as the Czech Republic (Brechler and Gersl, 2014), supranational institutions like the European Parliament (Kovats, 2009), staggered legislations such as those of Germany and Japan, (Goetz et al. 2014) and semi-presidential systems like France (Padovano and Gavoille, 2017). Yet all these tests have been conducted on samples where the level of democracy is quite high (Polity IV scores of 8 and more) and, most of all, constant over time. The PLC theory has never been verified in a country evolving from a de facto autocracy to a true democracy. This evolution enables testing two additional predictions of the PLC theory, beside the standard ones. First, as political competition increases and the systems of checks and balances and electoral control

\section{Accepted manuscript}


become more efficient, legislative cycles should become more evident, because legislators resort more to the vote-maximizing strategies that generate the cycle (Padovano, 2017). Second, to the extent that political competition develops in the legislative branch sooner than in the executive one (because in a first stage of the transition the forces that controlled the government during the autocratic period remain entrenched in the executive branch, as it was the case in Korea under the presidency of Roh Tae-woo), the number of law proposals and the magnitude of the cycle should be greater in the laws of parliamentary initiative. None of these hypotheses has ever been examined in the PLC literature so far. In this paper we test them on a newly assembled dataset that covers the legislative production of the first 19 legislatures of the Republic of South Korea, from May 1948, when the Republic was established after the end of WWII, to May 2016, the last legislature for which a full dataset about the legislative production of the Korean National Assembly is available. To anticipate the results of the empirical analysis, the estimates lend support to both predictions.

In the context of the literature on conditional political cycles, this paper differs from most of the existing literature because it derives the institutional variability from the analysis of a single country over time, instead of a panel of countries (Shi and Svensson, 2006; Brender and Drazen, 2008; Alt and Lassen, 2006) or of subnational jurisdictions (Akhmedov and Zhuravaskaya, 2004). All these papers obtain the institutional variability from the variance between their samples, while in our study it is the variance within that drives the results. This reduces the possibility of omitting relevant differences between countries that might affect the results. Moreover, the focus on legislative production, rather than on budgetary outcomes, shortens the transmission mechanism linking political decisions to outcomes; every type of decision, also those determining the size of the budget, actually passes through the intermediary step of the production of laws. Such a shorter chain further reduces the possibility of omitting relevant conditioning factors.

The rest of the paper is organized as follows. Section 2 describes the institutional

\section{Accepted manuscript}


evolution of South Korea and how it affected the legislative process. Section 3 presents the logic of the PLC model and extends its main predictions to the case of a country undergoing a process of democratization The fourth section illustrates the data about the legislative production. Section 5 discusses the empirical model, whose estimates are presented in section 6. Finally, section 7 draws the main conclusions of the analysis.

\section{The institutional evolution of South Korea}

2.1. Political evolution of South Korea. The Republic of South Korea was officially born in May 1948, after the liberation of the Korean peninsula from the domination of the Japanese Empire and the acceptance of the $38^{\text {th }}$ parallel as the dividing frontier between the two states of North and South Korea. Being (still) one of the countries that WWII left divided, throughout its history South Korea has been the theatre of a confrontation between the world's superpowers and their different ideologies, whose consequences have reverberated into its domestic political life. Albeit the country has always been proposed as a "showcase for democracy", in contrast to the communist regime of North Korea, for almost 40 years the democratic institutions of South Korea were mostly formal (Han, 2013). The government was in fact an autocracy, for long periods in the hands of the same leader; there were two military coups d'état (in May 1961 and in December 1979) and at least nine major constitutional reforms, summarized in Table 1 (Secretary of the National Assembly, 2008).

\section{[Table 1 about here]}

Autocratic rule and constitutional reforms are tightly connected in the history of South Korea because each of three Presidents-autocrats of South Korea between 1948 and 1988 (Seungman Rhee, Park Chung-hee and Chun Doo-whan) eventually faced the problem of strengthening or extending their grip on power beyond what was de jure allowed by the existing institutions. As table 1 illustrates, the first five constitutional reforms extended the duration of the presidential mandate, reinforced the powers of the executive, prevented

\section{Accepted manuscript}


the development of an effective system of separation of powers and checks and balances and thwarted the efficiency of the electoral control (Freedman, 2006)2. Throughout this period, corresponding to legislatures 1-12, the Republic of Korea is characterized by fairly low scores in the Polity IV index of democracy. Figure 1 shows that, before 1987, Korea usually scored between -5 and +3 , with a median value of -4 , within the "anocratic range" 3 of the Polity IV classification ${ }^{4}$. In 1987, however, a series of popular demonstrations and strikes pushed the presidential candidate, Roh Tae-woo, to reach an agreement with the opposition forces, which resulted in another constitutional reform, this time aimed at limiting the power of the executive, protecting political opposition and freedom of the press and limiting corruption. Nonetheless, the same forces that ruled South Korea during the Fifth Republic remained in control of the executive branch during the first years of the Sixth Republic. The new president, Roh Tae-woo (1988-1993), was a former military and was supported by the same Democratic Justice Party that was the political vehicle of former autocrat Chun Doo-whan. Furthermore, the second president of the Sixth Republic, Kim Young-sam (1993-1998), despite being one of the opponents of Roh in the 1988 elections, in 1993 was elected as a candidate of the Democratic Liberal Party, the new conservative grand coalition that resulted from the merging of the Democratic Justice

2 Political parties have been weak players for a long time, since they often existed only to support the political intentions of their leader, especially his/her aspiration to become president; leaders often renamed and reshuffled their own parties as they deemed expedient for the current political circumstances, making the creation of a proper party system and of stable political coalitions quite difficult. Political repression also played a major role, as politicians of left-wing parties were often imprisoned or had to escape to North Korea, especially after the war (Freedman, 2006; Park, 2001). This pattern still characterizes legislative politics in the Sixth Republic, as many MPs change parties to maximize their chances of being reelected (Shin, 2013)

${ }^{3}$ In this period South Korea marked a score of +8 (democracy) for a very brief spell (one year, 196061), during the so-called "Second Republic", following the resignation and the exile of Syngman Rhee and the repeal of the severe curbs on freedoms of political expression that had been in place under Rhee's regime. It proved to be a false dawn, however, as the military coup d'état of May 1961 brought the Polity IV score back to -6 (autocracy).

4 Specifically, the Polity IV metric ranges from -10 to +10 , with -10 to -6 corresponding to "autocracies", -5 to 5 corresponding to "anocracies", and 6 to 10 to "democracies". Anocratic regimes are loosely defined as partly a democracy and partly a dictatorship, i.e., they are regime types with democratic institutions that allow for purely nominal amounts of political competition and electoral control.

\section{Accepted manuscript}


Party of Roh with the two main opposition parties; plainly, Kim Young-Sam had to reach a compromise with the political élites of the autocratic period in order to be elected to the presidency. It took the second half of Kim Young-sam's mandate, with the arrests of Chun Doo-whan and Roh Tae-woo, and finally the presidency of Kim Dae-Jung (1998-2003) to observe consistent signs that the grip of the military élite on the executive branch had vanished (Freedman, 2006).

[Figure 1 about here]

2.2. Separation of powers. The Constitution of the Sixth Republic foresees an executive branch, headed by a president and an appointed prime minister, a unicameral legislature, called the National Assembly, and an independent judiciary, thus ensuring the separation of powers. Both the President and the National Assembly are directly elected by the people, respectively for a 5 and a 4 years long tenure. Albeit usually labelled a presidential system, the government of South Korea shares many features of France's semi-presidentialism, especially the presence of a Prime minister, appointed by the President with the consent of the National Assembly. This consent falls short, however, of a true confidence relationship, since the National Assembly may pass just a recommendation for the removal of the Prime Minister out of lack of confidence. Only when the President, the Prime Minister, or ministries violated the Constitution or other acts in the performance of their official duties, the National Assembly may pass motions for their impeachment.

The Constitution of 1988 stabilized the country's political life and transformed the Republic of Korea in a true democracy. The descriptive statistics of Table 2 confirm that; before 1988 the median Polity IV score was -4 , while it rose to 8, one of the highest scores in Far East Asia, after the promulgation of the Constitution.

[Table 2 about here]

Looking at the shares of the Assembly's seats held by the party supporting the president confirms the democratic evolution of the Republic of Korea (Moon, 2012). Although the presidential and the parliamentary elections are staggered, because the two

\section{Accepted manuscript}


mandates are (and have always been in the past) of different lengths, Table 2 shows that between 1948 and 1987 the party of the president held majorities within the interquartile range $53,6 \%-62,9 \%$. Conversely, in the legislatures $13-19$, finding a majority has not always been an easy task, since the median share of parliamentary seats held by president's coalition has been just above $50 \% .^{5}$

2.3. The legislative processes. What matters the most for the purposes of our study is how the evolution of the political institutions of the Republic of Korea have affected legislative production. In this respect, it is quite interesting that, throughout all its history and constitutional variations, the Republic of Korea has always foreseen the right to initiate the legislative process for both the executive and the legislative branch (respectively labelled "laws of government assignment" and "laws of parliamentary proposal"). Such a distinction is crucial in our empirical strategy, because it allows verifying whether: 1) the two types of laws - which express the initiatives of the two government branches - are characterized by different legislative cycles; and 2) the magnitudes of these two cycles changed as the country became more democratic and more exposed to the vote maximizing strategies that generate the cycle.

During the autocratic period, especially between the Third and the Fifth Republic (1963-1987), legislative production was characterized by the dominance of the executive branch over the legislative. Parliamentary elections were characterized by restricted competition, closed doors selection of candidates and, quite often, abuses of power over the legislators by the President-autocrat (Croissant, 2002; Hahn, 2013), which resulted in large vote margins that the president's party held in the National Assembly. The legislative initiative of the parliament cannot therefore be considered as a challenge to the status quo coming from an alternative power base, even when it was exerted by the

5 The turnover rate of the MPs of the Assembly from one legislature to another or the share of reelected incumbents are potentially other indicators of the actual level of democracy of a country, inasmuch as they reveal how contestable parliamentary seats are. In the context of South Korea, however, MPs not only have the habit of switching parties to be re-elected, but they often change positions of power within the various branches of the government, especially during the autocratic period. We hence believe that the electoral margin of the government's party is a more revealing indicator than the turnover rate of the MPs.

\section{Accepted manuscript}


opposition parties (Croissant, 2002). Moreover, the absence of a "reserve of law", i.e., a constitutional provision that restricts certain policy matters to legislation of parliamentary initiative, further reduced the separation of powers between the legislative and the executive branches, reinforcing the control of the latter over the former. ${ }^{6}$ Indirect evidence of this control comes from Figure 2, which reports the number of laws of government assignment and of parliamentary proposal approved during the first 19 legislatures. Before 1988 laws were relatively few and the ones of government assignment usually outnumbered those of parliamentary proposal. Instead, after the promulgation of the 1988 Constitution, the overall legislative production rose and the legislative branch got the upper hand over the executive in terms of legislative output. Figure 2 shows that, beginning with legislature 16 (2000-2004), laws of parliamentary proposal surpassed those of government assignment and took a steep acceleration, outnumbering them, during the $19^{\text {th }}$ legislature, by a ratio of six to one. This dynamics suggests that only during the Sixth Republic the legislative branch became a recognizable alternative power base to the executive (Croissant, 2002).

[Figure 2 about here]

In terms of legislative processes, the 1988 Constitution maintains certain features unchanged with respect to the previous regimes, but it innovates in others. The high substitutability between laws of government assignment and of parliamentary proposal, inherited from the autocratic period, is now constitutionally protected; art. 52 of the Constitution states that "Bills may be introduced by members of the National Assembly or by the Executive", without distinguishing between the two types in terms of subject matter. The only exception is the budget bill, which is of government assignment, and must be discussed and approved by the Assembly (art. 54). Conversely, the processes that bills of parliamentary proposal and of government assignment must follow are somewhat different. As for the laws of parliamentary proposal, any MP can introduce a bill with the

${ }^{6}$ During the Yushin Constitution the President had also the right to suspend the constitutional legislative procedures and to rule by decree.

\section{Accepted manuscript}


consent of 10 other members; alternatively, each Assembly committee may propose a bill in the name of its chairman. Once a bill is introduced to the Assembly, the Speaker reports it to the plenary session and refers it to the competent committees; after their examination and the general debate, the plenary session shall vote on the bill. Compared with the laws of parliamentary proposal, bills of government assignment follow a process that requires more consents within the executive itself. The Ministries in charge of shaping policies may draft bills on matters under their respective jurisdictions, consulting with other Ministries concerned, until they find an agreement. The bill must then be "published in advance", for no less than 20 days, to make its content known to the public. Right after comes the examination of the Ministry of Government Legislation, which examines formal aspects. Before the deliberation in the State Council, there is also an examination by the Ministry of Government Legislation; then, if deliberated by the State Council, the bill must be signed by the President and countersigned by the Prime Minister and the Minister of competent Ministry. At that stage it is submitted to the National Assembly, which can approve, reject or amend the bill. Hence, the two legislative procedures do not reveal major differences in terms of duration, except for the 20 days publication period that only bills of government assignment must respect; the time elapsing from the first proposal of either type of bill until its final approbation seems to depend more on political circumstances than on its institutional nature. Just like in other parliaments, the Speaker of the National Assembly decides the calendar of the bills to be discussed during each session, which endows him with the power to set the agenda. Only in matters related to the budget, the executive branch proposes the bill in a time frame fixed by the Constitution; in this case the President is the agenda setter.

The legislative activity of the Korean National Assembly is not continuous, but respects a calendar of legislative sessions during which the parliament is open (art. 47). Currently, the Assembly is open for 100 consecutive days starting from September $1^{\text {st }}$ (the so-called “ordinary session"), plus during four "special sessions", which may be called upon on February $1^{\text {st }}$, April $1^{\text {st }}$, June $1^{\text {st }}$ and August $16^{\text {th }}$ by either the president or by $1 / 4$ of the

\section{Accepted manuscript}


members of the Assembly; these special sessions may last up to 30 days. In all other periods the National Assembly is closed and no legislative production takes place. ${ }^{7}$ The calendar of the legislative sessions clearly affects the identification of the periods when a higher than normal legislative production can be expected; if the last regular session of the Assembly closes well before new elections are held, it will be impossible to find a peak of legislative production right before the elections, as it is instead the case in parliaments that are open almost for the entire year.

The regular duration of the legislature has been respected in most of the legislatures, except for legislature 1 (when the Korean War started) and for the legislatures called off early because of unpredictable events not related to the regular legislative process, such as social upheavals (legislature 4), coups d'état (legislatures 5 and 10), or constitutional reforms (legislatures 8 and 12). During the Sixth Republic no legislature ever ended prematurely, at least so far. Table 3 illustrates the sequence of all the legislatures of the Korean National Assembly included in our sample.

[Table 3 about here]

\section{The logic of the PLC extended to a country undergoing a process of democratization}

Applying the theory of PLC to the case of a country that, over time, is undergoing a process of democratization and that, at any point of time, presents features of both a democracy and of an autocracy, requires some adaptation of the standard PLC model. The original model (Padovano 2017; Lagona and Padovano, 2008) presupposes that legislative production takes place in a democratic setting, where political competition is functioning and the systems of checks and balances and electoral control are efficient. In such a setting the model predicts that legislative peaks occur right before the elections as a result of the vote-maximizing strategies that legislators implement in order to be re-elected by the voters. If the re-election of the legislator depends more on securing the support of the de duration.

7 The previous legislatures too had legislative sessions, although with different calendars and

\section{Accepted manuscript}


facto autocrat rather than on maximizing voters' welfare, the legislative cycles should become less evident. In this case the logic of the standard PLC model must be modified to account for the fact that incentives to please voters via legislative cycles may vary depending on the surrounding institutional environment. This connects the PLC theory with the parallel models of conditional political cycles literature.

In a full democracy the PLC model posits that the timing of legislative production is the equilibrium result of the interaction between three (sets of) agents: 1) an incumbent government seeking re-election, called the "legislator"; 2) low-information voters and 3) a special interest group. On the demand side of the political market, the special interest group differs from low-information voters as it is better informed about political decisions and can transfer private resources to the incumbent government. In return for votes from low-information voters and of votes and resources from the interest group, the legislator supplies two types of goods, characterized by different redistributive profiles: a general public good and a targeted club good. Low-information voters demand the former, while the special interest group seeks the latter. To supply these goods, the legislator must use resources (e.g., tax revenues) and approve legislation. To this end, he may choose among two alternative (but equally available) legislative instruments: "laws" that require the approbation of the majority of the parliament, and by that are assumed to be visible to all agents, even low-information voters; and "decrees" that do not require a parliamentary vote and are therefore visible only to the better informed special interest group. The different information costs of the two sets of agents lead the re-election seeking legislator to use laws for the supply of the general purpose good to the benefit of low-information voters, and decrees for the supply of the targeted good to the special interest group. The model also shows that, to signal his competence, separate himself from less competent challengers and maximize the number of votes from low-information voters, the incumbent legislator generates an electoral cycle of the general public good at the end of the legislature, thus concentrating the approbation of laws at that time. Since a less competent challenger might mimic this strategy, the competent legislator separates

\section{Accepted manuscript}


himself out by gathering private resources from the special interest group beforehand, so to boost the production of the general public good at the end of the legislature. To obtain these resources, the incumbent government must generate a pre-electoral cycle of the targeted good, which leads him to concentrate the approbation of decrees before the end of the legislature. The model thus predicts two opposite cycles in the production of decrees and laws: the approbation of less visible decrees will be clustered at the beginning of the legislature, while that of laws towards its end. Given the data available for the Republic of Korea, we will be able to test only the dynamics of laws, not of decrees.

In an anocratic regime, instead, like that of the Republic of Korea, which at any point of time has features of both an autocracy and a democracy, the incumbent legislator still aims at being re-elected; to reach this goal, however, he must maximize a "support function" that depends on the level of utility that his activity provides, on the one hand, to the autocratic President and, on the other, to the voters. The relative weight of these two utilities depends on the degree of democracy of the country, i.e., on the importance that voters have in securing the reelection of the legislator relative to the President.

Just like any model where accountability to voters is an endogenous result (Persson et al. 1997), a tradeoff is supposed to exist between the utility of the President and of the voters. In particular the President's welfare depends on the consumption of private goods whose production is financed via tax revenues; the alternative use of such revenues is the production of public goods that provide utility to voters. The legislator contributes to the production of both private and public goods by approving the necessary legislative acts. For simplicity, we assume that the President proposes the laws targeted at obtaining the private good he is interested in and that voters similarly demandto the Assembly laws aimed at supplying the public good. The problem of the legislator is deciding how many laws of each type to approve; this ratio determines how many private and public goods will be supplied. In this respect the actual degree of democracy plays the crucial role. As the political system of the country becomes more democratic, the legislator will attribute greater importance to pleasing the voters, by approving more laws and fewer decrees, in

\section{Accepted manuscript}


order to supply relatively more public goods. In this case the model approaches the standard PLC model and its predictions. Conversely, the more the regime is autocratic, the more the reappointment of the legislator depends on the support he receives from the president. To secure it, he will approve relatively more decrees to have more private goods being produced. For such a case the explanatory power of the standard PLC model becomes lower. We can therefore derive the first prediction of the PLC applied to the case of a country undergoing a process of democratization:

H1) As the degree of democracy increases, the legislative cycles should become more evident, since legislators adopt relatively more the vote-maximizing strategies that generate the cycle.

The fact that throughout its institutional evolution the Republic of Korea has always featured laws of both presidential and parliamentary initiative suggests another "out of model" prediction, which logically derives from $\mathrm{H1}$, although it actually presupposes an additional implicit assumption. If the process of democratization spreads first in the legislative branch than in the executive one, the incentives to implement the votemaximizing strategies that generate legislative cycles should be stronger there. Hence, we should expect that:

H2) The magnitude of both legislative initiatives and of legislative cycles should be greater in the laws proposed by the parliament.

Being an "out of model" prediction, the plausibility of $\mathrm{H} 2$ as an interpretation of any estimated result consistent with it requires that the democratic evolution of the country actually developed in the legislative branch first. This assumption is quite realistic in the context of the Korean democratization process, as we have seen that the élites that expressed the autocrat before 1988 remained in control of the executive branch for some time even during the Sixth Republic. Moreover, during the autocratic period, legislators affiliated to the (largely) majoritarian president's party had few incentives to cater the interest of voters, since their reappointment depended more on signaling their loyalty to

\section{Accepted manuscript}


the autocrat than on proving electorally accountable in purely nominal elections; hence they had no reason to generate a PLC during the autocratic period. In the framework of the 1988 Constitution, instead, legislators have some incentives to signal competence to voters also by approving laws of government assignment, since these must be passed by the National Assembly too, even though MPs cannot take credit for having initiated the legislative process. After 1988 we can therefore expect a PLC also in the laws of government assignment, even though of smaller magnitude that the one registered in the laws of parliamentary proposal, as stated by $\mathrm{H} 2$.

$\mathrm{H} 1$ and $\mathrm{H} 2$ are the main variations to the standard predictions of the PLC model that are specific to a country undergoing a process of democratization. In addition to them, the logic of the standard PLC model applies and allows to identify the control variables for the regression model of the next section. These must be of course adapted to the specific features of the Republic of Korea and to the data available. According to the standard PLC theory, the number of laws depends on the size of the government majority over the minimum required for approving a law, on the fragmentation of the government majority, on the timing of the parliamentary closures and on a number of other factors specific to the sample under scrutiny (Lagona et al. 2015; Padovano and Gavoille, 2017).

\section{Description of the data}

Our dataset includes all laws ("legislative Acts" in the jargon of the Constitution) approved since July 1948, when the first legislature was inaugurated, till May 2016, when the $19^{\text {th }}$ legislature of the National Assembly ended (the one active at the time of writing this paper is the $\left.20^{\text {th }}\right)$. Figure 3 illustrates the total amount of laws approved by the National Assembly of South Korea in the 631 months that correspond to the total duration of the legislative sessions open through these 19 legislatures Data take the form of monthly counts, with a lower bound of 0 and values that are positive integers. A solid vertical line indicates the regular end of a legislature, while a dashed one denotes legislatures that ended prematurely. The figure shows that legislative production is

\section{Accepted manuscript}


characterized by an upward trend, which becomes much steeper in more recent legislatures. Peaks of legislative production are also more evident in the legislatures that end up at the regular, expected time, especially after the constitutional reform of 1988; yet they seem to be placed near but not right before the closing of the legislature, due to the schedule of the legislative sessions. Both circumstances appear however consistent with the PLC theory; in particular, the lower legislative production that characterizes legislatures 1-12 reflects the tight control that executive exerted on the legislative branch during the autocratic period, as well as the lack of political competition due to the large majorities that the presidential party enjoyed then (Croissant, 2002; Han, 2013). With no real political competition, legislators had no incentives to concentrate the approbation of laws at the end of the legislature to signal competence to voters, consistently with $\mathrm{H} 2$. Conversely, in the legislatures 13-19, which followed the constitutional reform of 1988, political competition seems to produce the incentives to signal competence to voters and therefore to generate a legislative cycle.

[Figure 3 about here]

Figure 4 and 5 report the monthly counts of laws disaggregated between those of parliamentary proposal and of government assignment, respectively. As in the case of the total counts of laws, the cycle does not seem to emerge in the legislatures that ended prematurely. The cycle instead appears more evident in the laws of parliamentary proposal, while for those of government assignment an end-of legislature spike is evident only in legislatures 14 (mainly devoted to the reconstruction of democracy after the constitutional reform of 1988) and 15 (when the government had to deal with the serious financial crisis that hit Asia in 1997).

\section{[Figures 4 and 5 about here]}

\section{The hurdle regression model}

As in the rest of the PLC literature, the empirical analysis of this paper focuses on two data series in the form of monthly counts of laws: one for the monthly counts of laws of

\section{Accepted manuscript}


parliamentary proposal, the other for those of government assignment. Figure 6 displays the distributions of both series on a square-root scale ( $a k a$ "rootograms"); it shows that they are both zero-inflated and long-tailed. Zero-inflation arises because, in several periods of time, the Korean National Assembly failed to approve any law, either because it was not in a legislative session (the most common reason for the post-1988 subsample) or because it was closed or not active due to a coup d'état (the most likely explanation during the autocratic period). Whichever the reason, months with no law approved occur often throughout the sample period. On the other hand, the long tail of the distribution of the data is associated with extraordinary periods of higher than average legislative production.

[Figure 6 about here]

These features suggest modelling the count $l$ of laws approved during a month through a hurdle model (Cameron and Trivedi, 2013) that integrates two variables: one, $Z$, which indicates whether the National Assembly approved any law or not in any given month; the other, $l$, which measures the number of laws approved in any given month.

In the hurdle model, the first variable is specified as a binary variable

$$
Z(l)=\left\{\begin{array}{l}
0 \text { if } l=0 \\
1 \text { if } l>0
\end{array}\right.
$$

with a Bernoulli distribution

$$
p_{1}(z(l))=p_{1}^{z(l)}\left(1-p_{1}\right)^{1-z(l)}
$$

where $p_{1}(0)=P(l=0)=1-p_{1}$ indicates is the probability that the National Assembly does not approve any law, while $1-p_{1}(0)=P(l>0)=p_{1}$ is the probability that it approves a positive count of laws.

Variable $l$ is instead modelled by a negative binomial distribution, to accommodate the long tail of legislative production:

$$
p_{2}(l)=\frac{\Gamma\left(l+1 / \sigma^{2}\right)}{\Gamma\left(1 / \sigma^{2}\right) l !} p_{2}^{1 / \sigma^{2}}\left(1-p_{2}\right)^{l}
$$

where

\section{Accepted manuscript}




$$
\begin{aligned}
p_{2} & =\frac{1 / \sigma^{2}}{\lambda+1 / \sigma^{2}} \\
1-p_{2} & =\frac{\lambda}{\lambda+1 / \sigma^{2}}
\end{aligned}
$$

Here the parameter $\lambda$ indicates the mean of the distribution, while the variance is given by $\lambda\left(1+\sigma^{2} \lambda\right)$. When $\sigma^{2}=0, p_{2}(l)$ reduces to a Poisson distribution with mean $\lambda$; otherwise, $\sigma^{2}$ allows for a variance function that increases quadratically with the mean, thus capturing the overdispersion and the lengthening of the tail of the series.

The proposed hurdle model integrates the two variables by assuming that the number $l$ of laws approved each month by the parliament is given by:

$$
p(l)=\left\{\begin{array}{lr}
p_{1}(0) & \text { if } l=0 \\
\left(1-p_{1}(0)\right) \frac{p_{2}(l)}{1-p_{2}(0)} & \text { if } \quad l>0
\end{array}\right.
$$

In this setting, the mass probability $p_{2}(0)$ of the negative binomial at 0 is replaced by $p_{1}(0)$, to allow for zero-inflation, while the negative binomial distribution is retained for $l>0$, to allow for both the elongation of the tail and over-dispersion.

The model is completed by two non-necessarily identical vectors of covariates that modulate the means of the two variables of the hurdle model; they are introduced in the form of two row vectors $\boldsymbol{x}_{1}^{T}$ and $\boldsymbol{x}_{2}^{T}$. Specifically, the mean of the first variable - the probability $p_{1}-$ depends on the covariates through a logistic function with regression coefficients $\boldsymbol{\beta}_{\mathbf{1}}$, namely

$$
p_{1}=\frac{\exp \left(\boldsymbol{x}_{\mathbf{1}}{ }^{\boldsymbol{T}} \boldsymbol{\beta}_{\mathbf{1}}\right)}{1+\exp \left(\boldsymbol{x}_{\mathbf{1}} \boldsymbol{\beta}_{\mathbf{1}}\right)}
$$

In our final model, the row profile $\boldsymbol{x}_{\mathbf{1}}^{T}$ includes the intercept term 1 and:

1. The number $t$ of months elapsed between the beginning of the legislative session and the time of the observation. The regression coefficient of this variable is expected to be positive, since the probability of switching from a period when no laws are passed to

\section{Accepted manuscript}


one where they are approved in a strictly positive number should increase during the parliamentary session. This reflects the tendency, predicted by the PLC theory, that laws are approved in larger numbers towards the end of the legislative session and of the legislature.

2. The monthly count of sitting days of the National Assembly, to account for the fact that, since during the Sixth Republic the regular legislative session begins on September $1^{\text {st }}$ and lasts 100 days, the days available for legislating in the month of December will always be about $1 / 3$ of the previous three months. A positive coefficient is expected on this variable, because the monthly count of laws exogenously depends on the number of days the National Assembly is sitting in each month.

The mean of the second variable, the parameter $\lambda$, depends on the covariates through an exponential function with regression coefficient $\boldsymbol{\beta}_{2}$ :

$$
\lambda=\exp \left(\boldsymbol{x}_{\mathbf{2}}{ }^{\boldsymbol{T}} \boldsymbol{\beta}_{2}\right)
$$

In our final model, the row profile $\boldsymbol{x}_{2}^{T}$ includes the intercept term 1 and:

1. The number $t$ of months elapsed between the beginning of the legislature and the time of the observation. As already said, a positive coefficient on this variable is consistent with the PLC theory;

2. The percentage of the seats held by the government majority $k$. Larger majorities are characterized by lower costs of approving laws, which should increase the magnitude of the legislative cycle, regardless of the type of legislative instrument;

3. The value of the Polity IV index, as a proxy for the degree of democracy attained by the Republic of Korea in any year of the sample period. A positive coefficient on this variable lends support to $\mathrm{H} 1$;

\section{Accepted manuscript}


4. An interaction effect between the degree of democracy (proxied by a dummy variable $\delta$ that equals 0 in the legislatures 1-12 and 1 afterwards) ${ }^{8}$ and the month $t$ of the legislature, $t \times \delta$, to test whether the political regime affects the trend of legislative activity, according to hypothesis $\mathrm{H} 1$.

We omit from vector $\boldsymbol{x}_{2}^{T}$ some control variables usually included in regression models testing the PLC theory in other legislative environments that are not suitable for the Korean one. First, the PLC theory typically distinguishes between legislatures that reach their expected end and those that do not (Lagona and Padovano, 2008). A premature dissolution of the parliament reflects an impossibility for parties to generate a government majority, which disrupts the legislative activity and prevents the onset of a legislative cycle. In Korea, however, all the premature conclusions of the legislatures took place before the $13^{\text {th }}$ legislature, when the autocratic regime restrained legislative production. As a result, the dummy variable indicating a premature end of the legislature was never statistically significant. Nor we include the fragmentation of the government majority in the regression model because, as already mentioned, the Korean party system has always been extremely fluid and dependent on the political fortunes of the individual leaders, especially before 1987 and to some extent still today (Freedman, 2006; Shin, 2013). In such a context measuring the concentration of the government (or opposition) coalition could be quite misleading.

Finally, the presence of legislative sessions makes it difficult to identify a spike in legislative production at the end of the legislature, because the regular session, where the greatest number of laws is approved, may be scheduled at different time distances from the end of the legislature. We did try to capture the presence of legislative spikes by means of a dummy peak that equals 1 for different time distances from the end of the legislature (alternatively 15, 12, 9, 6 and 3 months before the end of the legislature) and 0 in the

\footnotetext{
${ }^{8}$ The stark difference of the two periods, shown by Table 2, allows representing the process of democratization of South Korea as a dummy variable discriminated around the end of legislature 12.
}

\section{Accepted manuscript}


previous months. The results of the estimates are rather inconclusive: only when the dummy is set at 12 months it becomes statistically significant during the democratic subsample. Such a result is indeed in line with the PLC theory, but 12 months amounts to a quite long and therefore non-discriminating time interval, as it is equal to $1 / 4$ of the total length of a regular legislature. All in all, the data seem to lend more support to the view that in South Korea the PLC takes the form of an upward trend of legislative production than of an end-of-legislature peak. Our final model therefore excludes dummies that reflect spikes of legislative activity at the end of the legislature.

\section{Estimation results}

Tables 4 and 5 report the results obtained estimating the effects of the explanatory variables on, respectively, the number of laws of parliamentary proposal and on that of government assignment, using the hurdle model described above. Each table includes two panels: the upper panel displays the effect of the covariates on the number of approved laws $l$, while the lower one reports the effect of the covariates on the probability $Z$ that the National Assembly is active.

[Table 4 and 5 about here]

In both tables, the estimate of $\log \left(1 / \sigma^{2}\right)$ is highly significant, supporting the choice of a negative binomial distribution. The pseudo $\mathrm{R}^{2}$ (Cragg and Uhler, 1970), displayed in both tables, indicates the departure from the null model without covariates. Their values suggest that the proposed specification is more adequate for the legislative activity prompted by parliamentary proposals (where the pseudo $\mathrm{R}^{2}$ is equal to 0.228 ) than for laws proposed by the government (where the pseudo $R^{2}$ is equal to 0.078 ). Figure 7 shows the goodness of fit of the two models. The top two panels, one for each type of legislative instrument, compare the observed and the predicted frequencies via hanging rootograms (Kleiber and Zeileis, 2016). The curve indicates the square root of the frequencies that the

\section{Accepted manuscript}


model predicts, while the length of the bars represents the square root of the observed frequencies. ${ }^{9}$ The two rootograms show that both models tend to underfit extreme frequencies, i.e., months when the production of laws is at its highest, but they provide a reasonable fit of the rest of the sample. The two bottom panels of figure 7 display the plots of the quantile residuals, again for each of the two legislative instruments (Dunn and Smyth, 1996). They reveal that the assumption of a negative binomial distribution is adequate for both laws of parliamentary proposal and of government assignment.

All in all, the lower panels of both table 4 and 5 confirm that the probability $Z$ that the National Assembly approves laws increases with the month $t$ from the beginning of the standing parliamentary session, even after adjusting for the number of days when the National Assembly is sitting. In other words, more laws tend to be approved at the end of a legislative session than at its beginning.

The upper panels of the tables, where the dependent variable is the number of laws $l$, further spell out this result. In both tables, the baseline effect of the month $t$ since the beginning of the legislature is not significant, but the interaction effect $\delta \times t$ is (p-values of 0.004 and 0.038 respectively). The combination of these results shows that legislation cycles took place only after the end of the $12^{\text {th }}$ legislature, i.e., only after the country had become democratic. This result confirms H1, since both the laws of parliamentary proposal and those of government assignment are characterized by an upward exponential trend from the beginning of the legislature till its end, controlling for the number of days in a month when the Assembly was open. In other words, all other things being equal during the democratic period more laws have been approved at the end of the legislature than at its beginning; this provides evidence of a legislative cycle. Importantly, the occurrence of this cycle is conditional to the attainment of a specific democratic threshold, in this case, a Polity IV score larger than 5. In addition, the magnitude of this

\footnotetext{
${ }^{9}$ The square root scale is employed to adjust for scale differences across the values, otherwise the deviations would be visible only for values with large observed/expected frequencies. Bars are drawn from the curve, so that they are "hanging" from it.
}

\section{Accepted manuscript}


effect seems greater in Table 4 (0.033), for laws of parliamentary proposal, than in table 5 (0.023), for laws of government assignment. This difference suggests that, while in the democratic period the total legislative production increased, the approbation of laws of government assignment grew at a lower rate, all other things being equal. This result lends support to $\mathrm{H} 2$, which holds that, as the country became more democratic, political competition developed in the legislative branch more than in the executive one; hence, both the number of legislative initiatives and the magnitude of the cycle is greater in laws of parliamentary proposal.

The legislative output is also positively correlated with the Polity IV index (coefficient 0.146 , p-value 0.000 ), which suggests that political conditions play a crucial role in the legislative process. Again, consistently with $\mathrm{H} 2$, such an effect is not statistically significant in the case of laws of government assignment (p-value 0.575).

Finally, as expected, the size of the majority has always, ceteris paribus, a positive and statistically significant impact on the approbation of both types of laws. Consistent with theory, the estimated coefficients are similar for the two types of legislative instruments: 0.028 for laws of government assignment and 0.026 for those of parliamentary proposal.

Finally, the estimates reported in tables 4 and 5 can be used to compute the predicted values of the legislative production process, obtained after discarding the months of inactivity of the National Assembly. Figures 8 and 9 display such predictions on a square root scale, along with $95 \%$ confidence bands computed on the basis of 500 bootstrap replications. The two diagrams show the dynamics of both types of legislatives processes, as predicted by the hurdle model for the entire 70 years of duration of the sample. The fitted value always lay within the confidence bands.

[Figure 8 and 9 about here]

\section{Accepted manuscript}




\section{Conclusions}

The first test of the PLC in a country, like the Republic of South Korea, undergoing a process of democratization has confirmed the standard predictions of the PLC theory, but it has also found new features of the legislative cycle, associated with the process of democratization. A hurdle model, estimated separately on laws of parliamentary proposal and of government assignment, has yielded two main findings. First, legislative cycles arise only when the country becomes a true democracy and increase as the democratic legislative practices consolidate. Second, as the party system and the mechanisms of legislative checks and balances develop, legislative production moves away from the executive towards the legislative branch of government; in addition, the production of laws of parliamentary proposal assumes a more pronounced cyclical pattern. Both phenomena can be explained by an extension of the standard model of PLC, applied to the case of a country undergoing a process of democratization.

These results provide a contribution also to the literature on conditional political cycles, especially in young democracies. The analysis shows that cyclical outcomes, in this case related to the approbation of laws, arise and change of magnitude as the surrounding institutional environment evolves. This paper in particular is one of the few contributions to conditional political cycle literature that proposes a time series result about a single country, whose process of democratization has been examined over a sample period of almost 70 years. For those reasons, the analysis of the legislative production in a quite demanding setting like the one presented by the parliamentary history of South Korea, characterized by several constitutional reforms, two coups d'état and, most importantly, an evolution from an autocratic to a democratic regime, corroborates the heuristic value of the PLC theory, and confirms that legislative cycles are a quite general phenomenon.

\section{Accepted manuscript}


References

Akhmedov, A. and Zhuraskaya, E., 2004. Opportunistic Political Cycles: Test in a Younf Democracy Setting. Quarterly Journal of Economics 119: 1301-1338

Aidt, T. S. and Mooney, G., 2014. Voting suffrage and the political budget cycle: Evidence from the London Metropolitan Boroughs 1902-1937. Journal of Public Economics, 112: 53-71,

Alt J., and Lassen, D. D., 2006. Fiscal Transparency, Political Parties and Debt in OECD Countries. European Economic Review, 50: 1403-1439

Brechler J., and Gersl, A., 2011. Political Legislation Cycle in the Czech Republic. Constitutional Political Economy, 25: 137-153

Brender, A. and Drazen, A., 2008. How Do Budget Deficits and Economic Growth Affect Reelection Prospects? Evidence from a Large Panel of Countries. American Economic Review, 98: 2203-2220.

Cameron, A. C. and Trivedi, P. K., 1998. Regression Analysis of Count Data. Cambridge, Cambridge University Press.

Center for Research of Assembly Politics, 2010. Korean National Assembly: Its Political Process (in Korean). Seul: Oruem.

Cragg, J.G. and Uhler R. S., 1970. The Demand for Automobiles. The Canadian Journal of Economics 2: 386-406.

Croissant, A. 2002. Electoral Politics of South Korea, in Croissant A., Bruns, G. and Marei, J. (eds.) Electoral Politics in Southeast and East Asia. Singapore, Friedrich Ebert Stiftung: 233-276.

De Haan, J. and Klomp, J. 2013. Conditional political budget cycles: a review of recent evidence. Public Choice 157: 387-410

Dunn, P. K. and Smyth, G. K., 1996. Randomized Quantile Residuals. Journal of Computational and Graphical Statistics 5: 236-244

Freedman, A. L., 2006. Political Change and Consolidation: Democracy's Rocky Road in Thailand, Indonesia, South Korea, and Malaysia. Palgrave Macmillan.

Goetz K., Stecker, C., and Willumsen, D., 2014. Staggering and Legislative Behaviour: The Upper Chambers of Germany and Japan, University of Munich working paper.

Han, B. (2013). History of Freedom of Korean Politics in the XX Century (in Korean). Seul: Ilchokak.

Kleiber, C. and Zeileis, A., 2016. Visualizing Count Data Regressions Using Rootograms. The American Statistician 70: 296-303

Kovats L., 2009. Do Elections Set the Pace? A Quantitative Assessment of the Timing of European Legislation. Journal of European Public Policy 16: 239-255

\section{Accepted manuscript}


Lagona F., and Padovano F., 2008. The Political Legislation Cycle. Public Choice, 134: 201229.

Lagona, F., Maruotti, A., and Padovano, F., 2015. Multilevel Multivariate Modelling of Legislative Count Data with a Hidden Markov Chain. Journal of the Royal Statistical Society: Series A (Statistics in Society), 178: 705-723

Moon, W. 2012. The Executive-Legislative Relationship and the Legislative Efficiency in South Korea (in Korean). Center for Research of the Evolution of the Korean Parliament.

Padovano F. 2017. A Theory of the Cyclical Production of Laws and Decrees. Centre Condorcet for Political Economy Working Paper 2017-09-ccr

Padovano, F. and Gavoille, N., 2017. Legislative Cycles in a Semi-Presidential System. Journal of Institutional and Theoretical Economics 173: 470-497.

Park, C., 2001. The Relationship between the Assembly and the Executive and its Evolution (in Korean). Research in Assembly Politics, 7 (2). .

Persson, T. Roland, G. and Tabellini, G., 1997. Separation of Powers and Political Accountability. Quarterly Journal of Economics 112: 1163-1202.

Rose, S. (2006). Do fiscal rules dampen the political business cycle? Public Choice 128: 407431

Secretary of the National Assembly, 2008. 60 Years of the National Assembly of the Republic of Korea. Secretary of the National Assembly.

Shi, M. and Svensson, J., 2006. Political budget cycles: Do they differ across countries and why? Journal of Public Economics 90: 1367-1389.

Shin, J. H., 2013. Voter Demands, Access to Resources, and Party Switching: Evidence from the South Korean National Assembly, 1988-2008. Japanese Journal of Political Science 14: 453-472

Wittman, D., 1997. The Myth of Democratic Failure. Chicago: University of Chicago Press.

\section{Accepted manuscript}




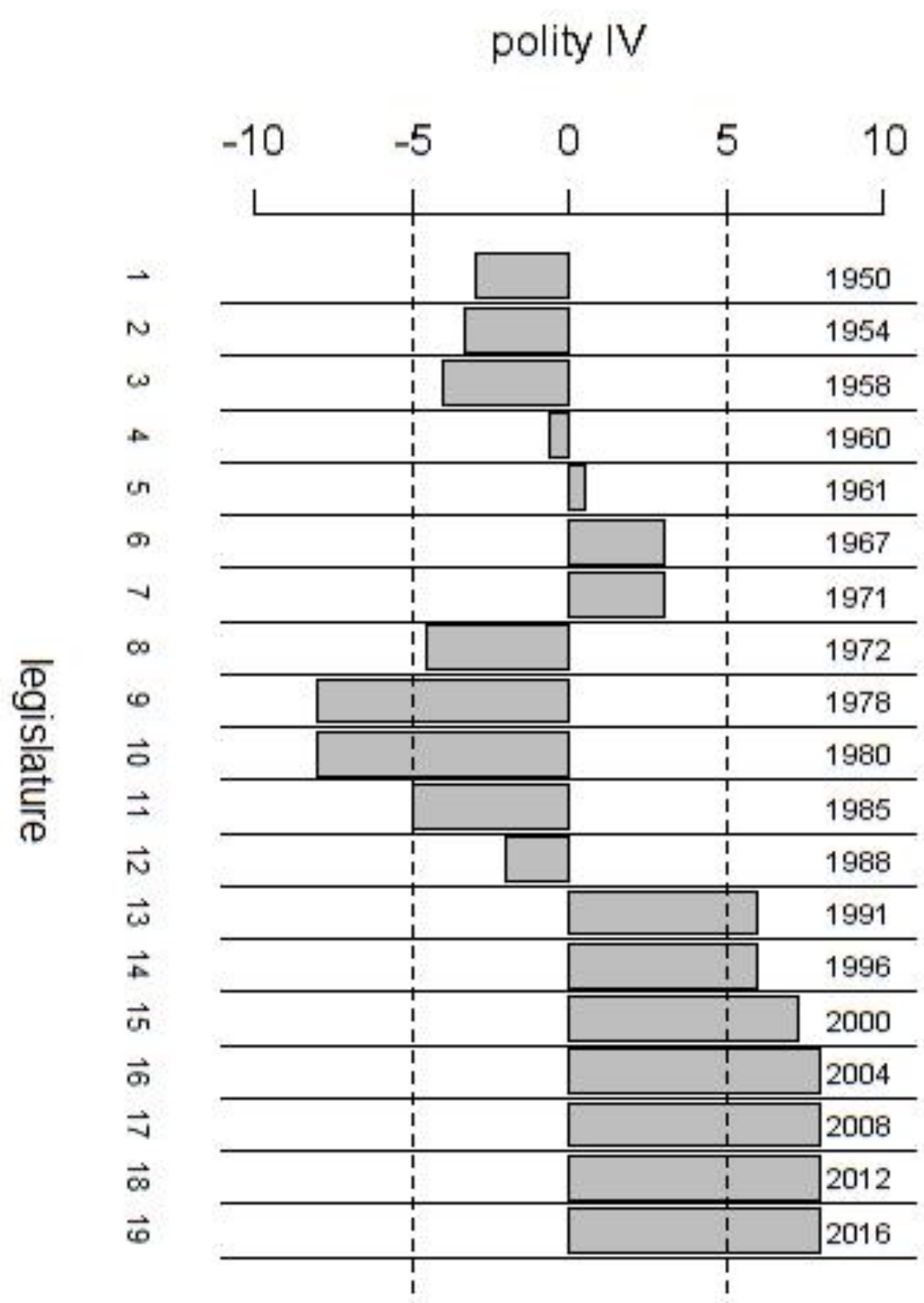

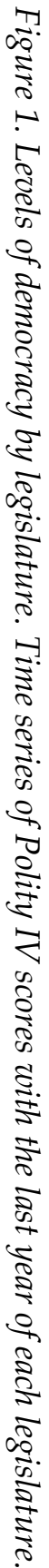

\section{Accepted manuscript}




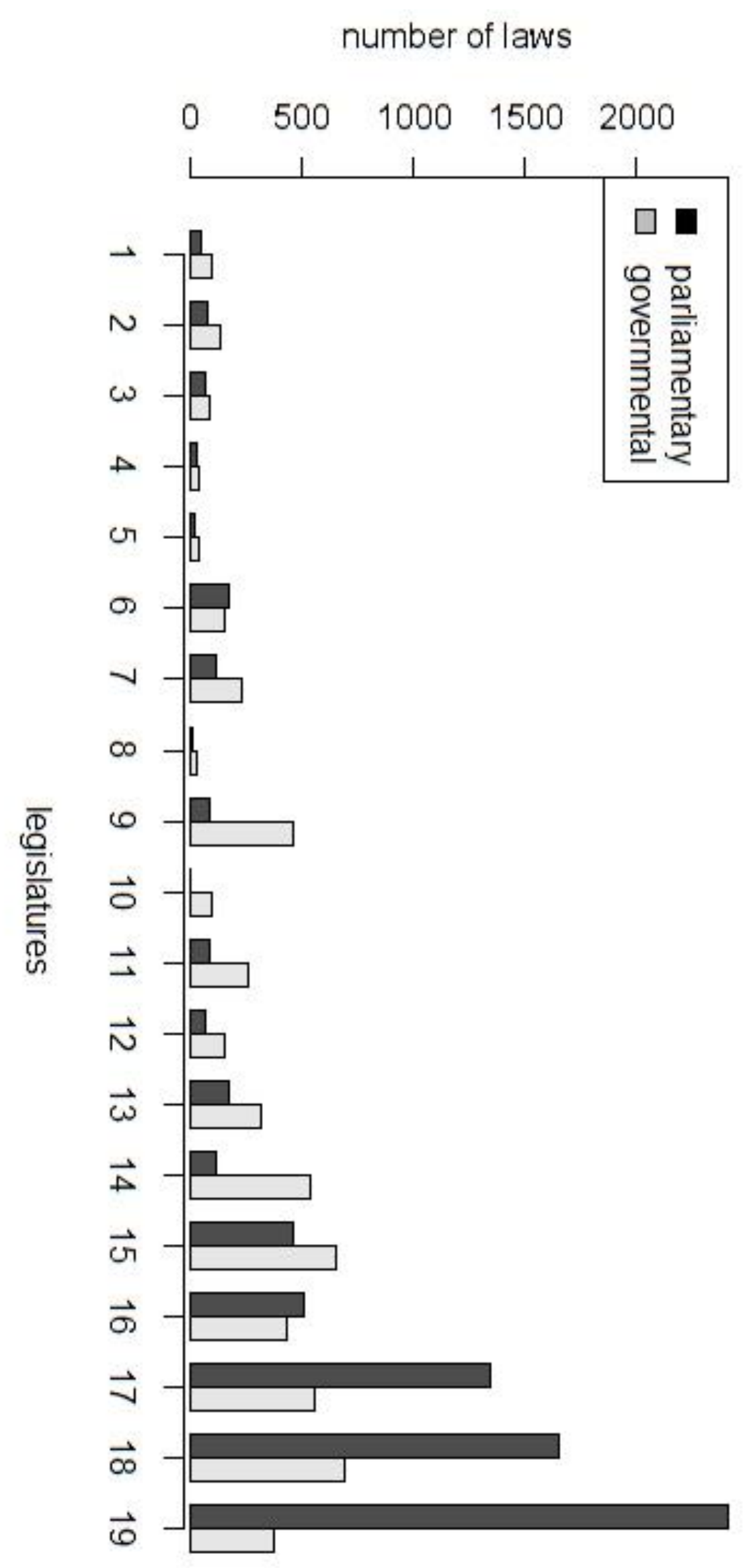

Accepted manuscript 


\section{number of laws}

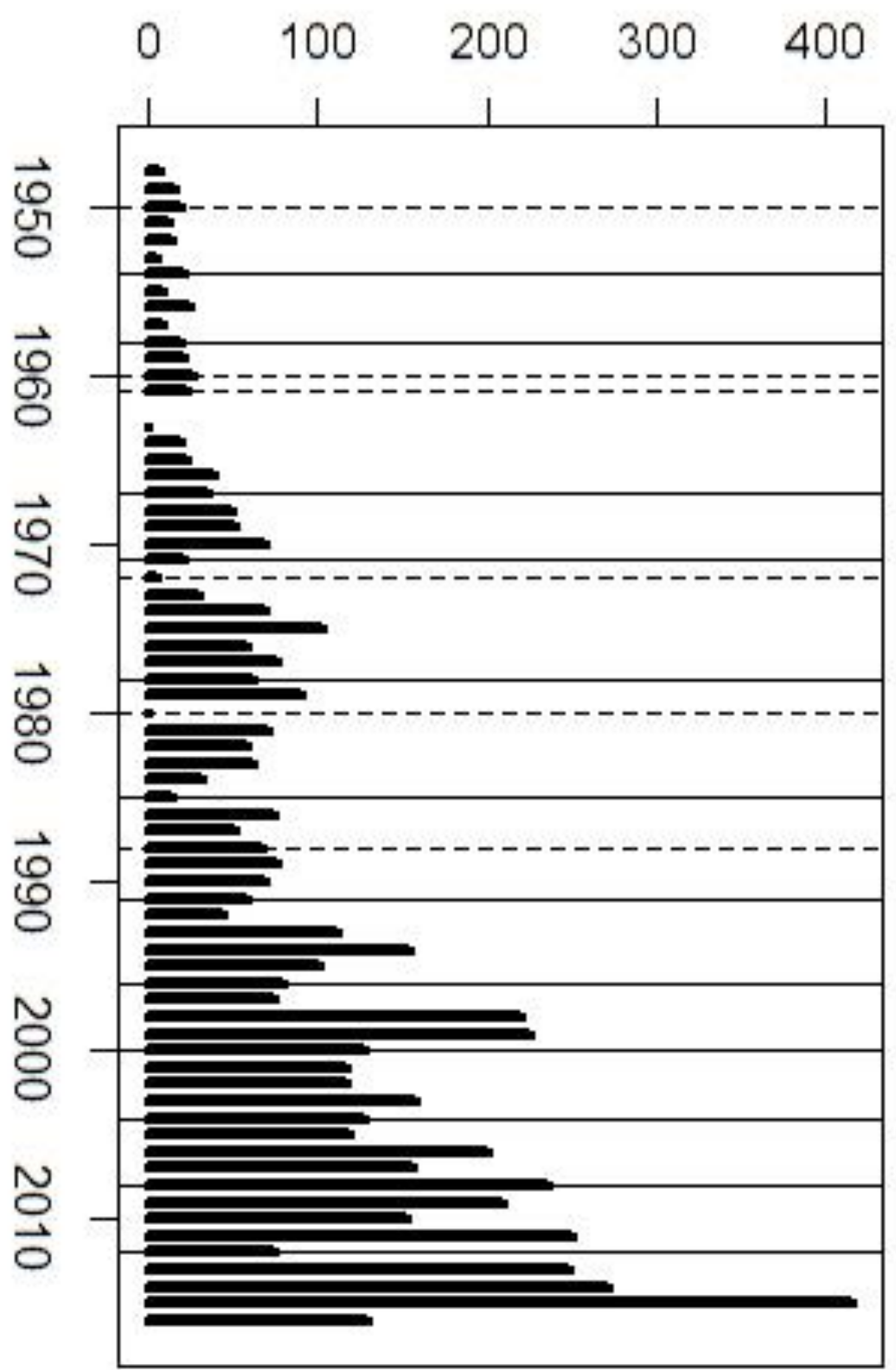

\section{Accepted manuscript}




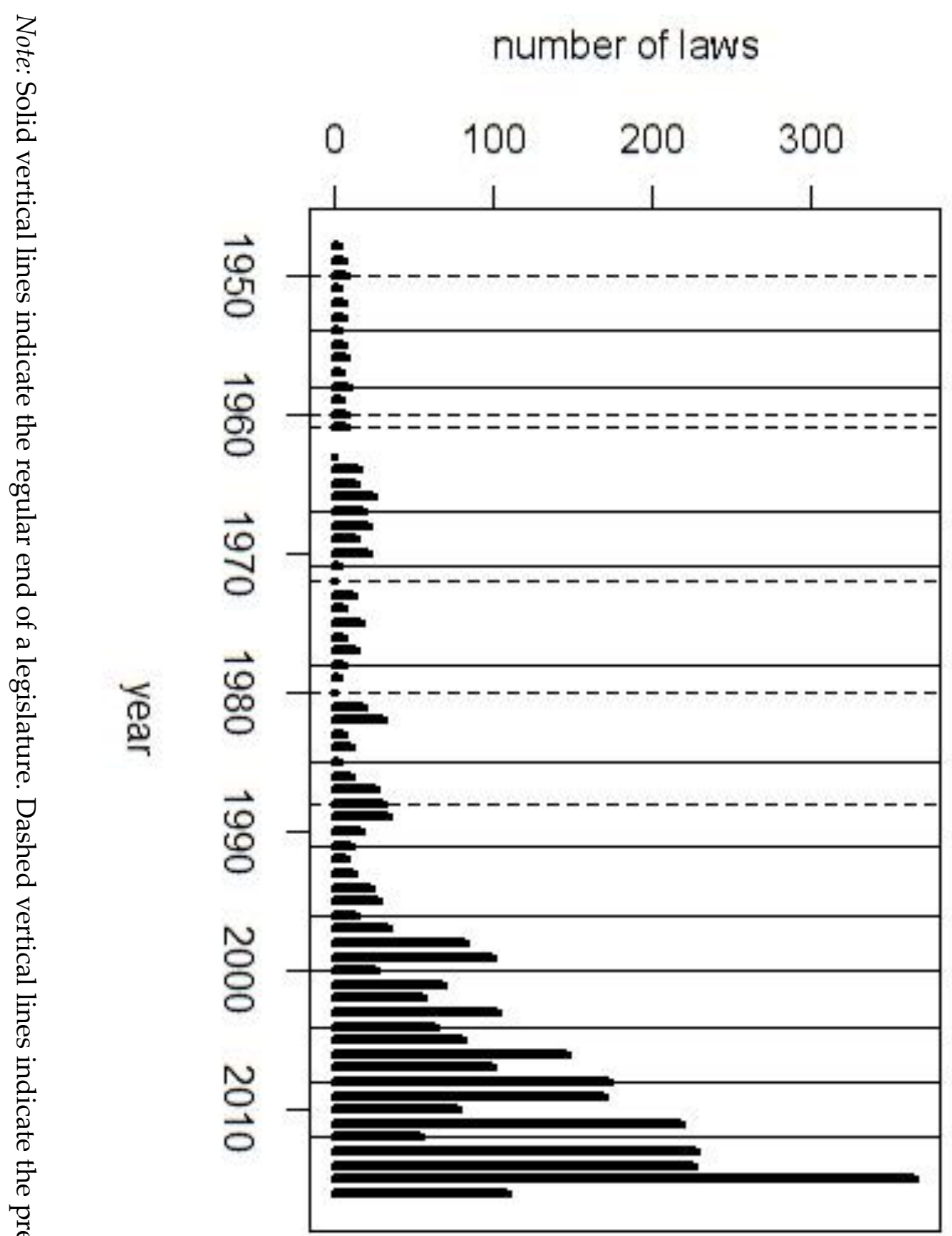




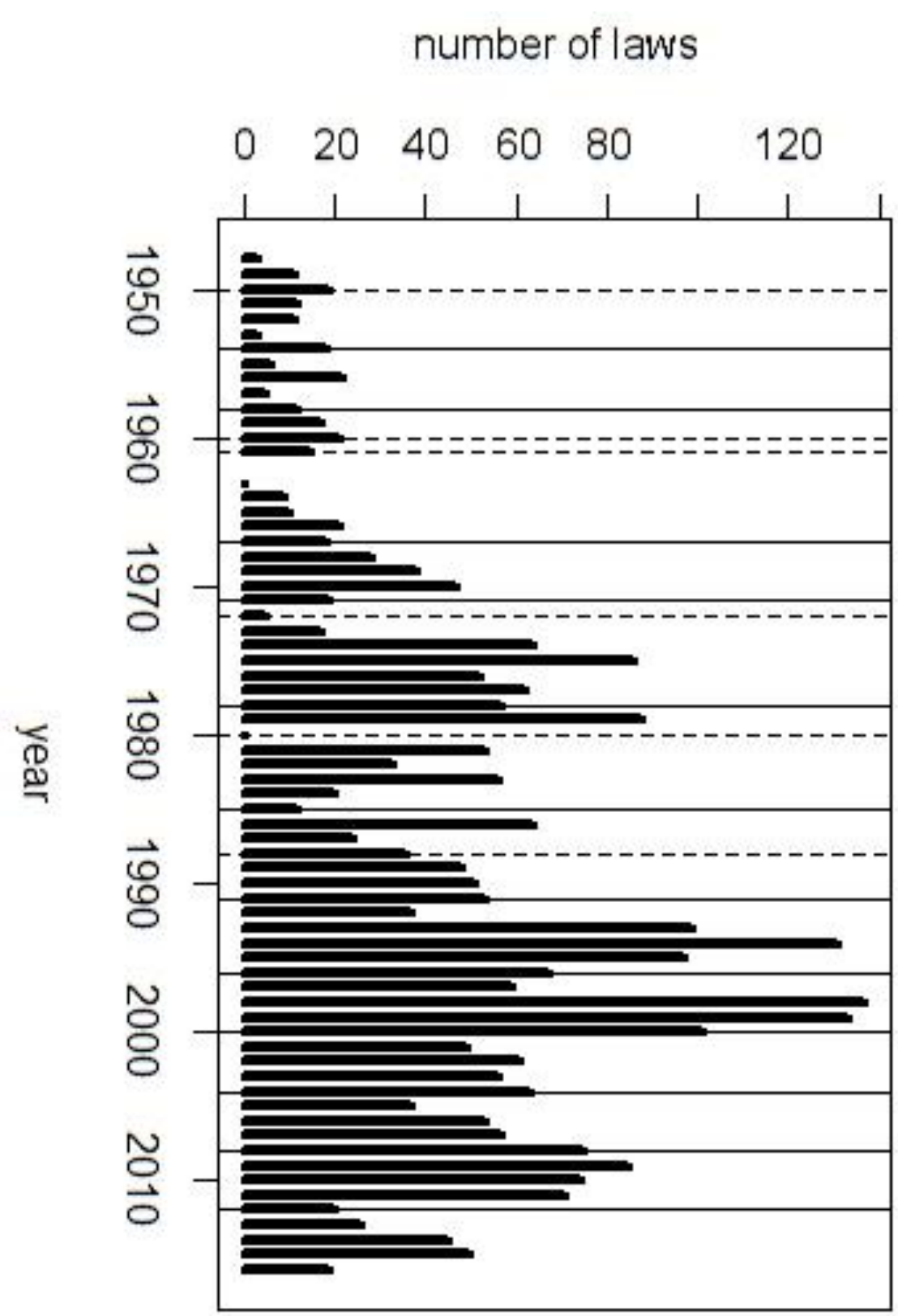


Figure 6 Rootograms of the number of approved laws of parliamentary proposal (top) and of government assignment (bottom)
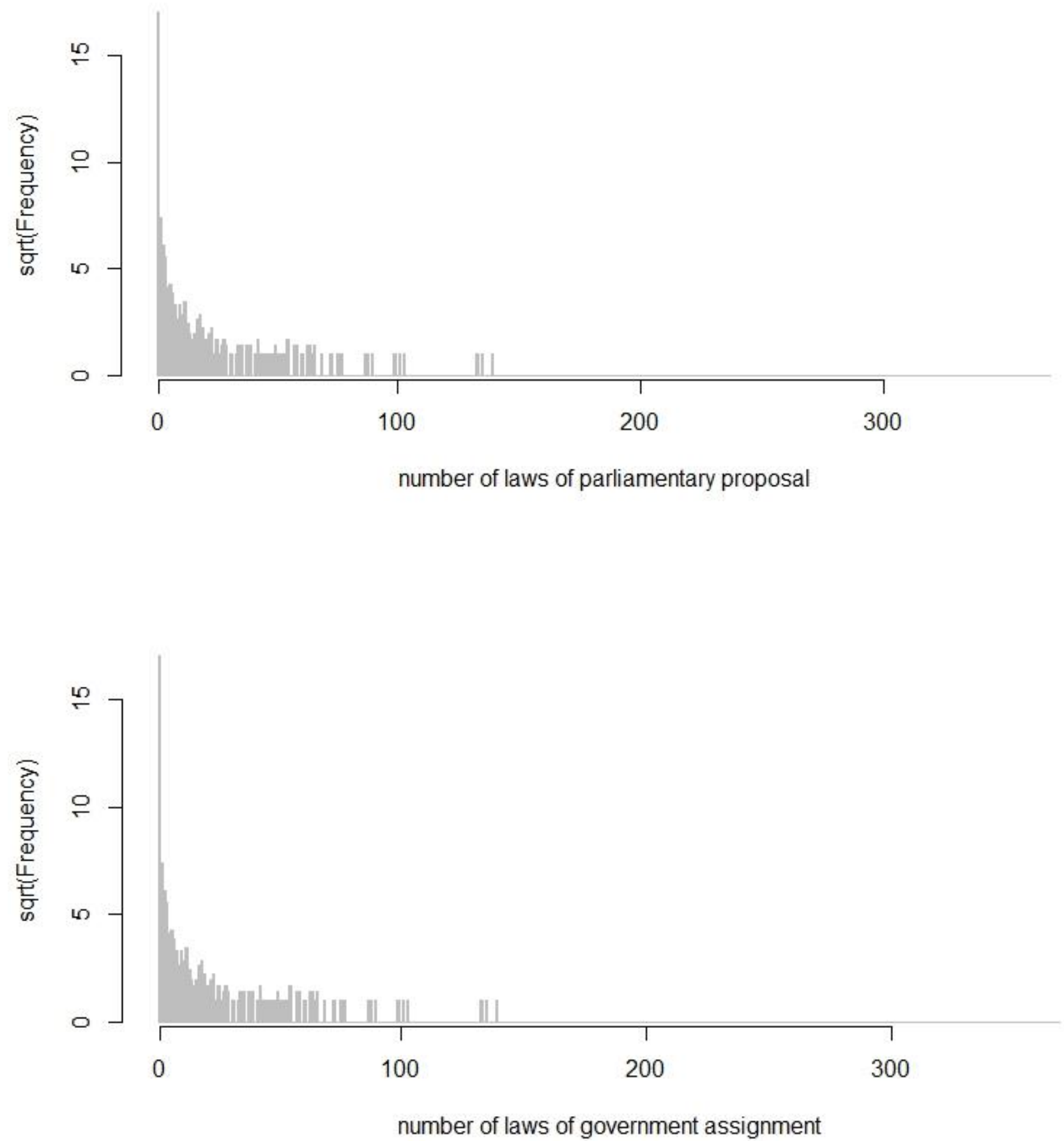

Accepted manuscript 


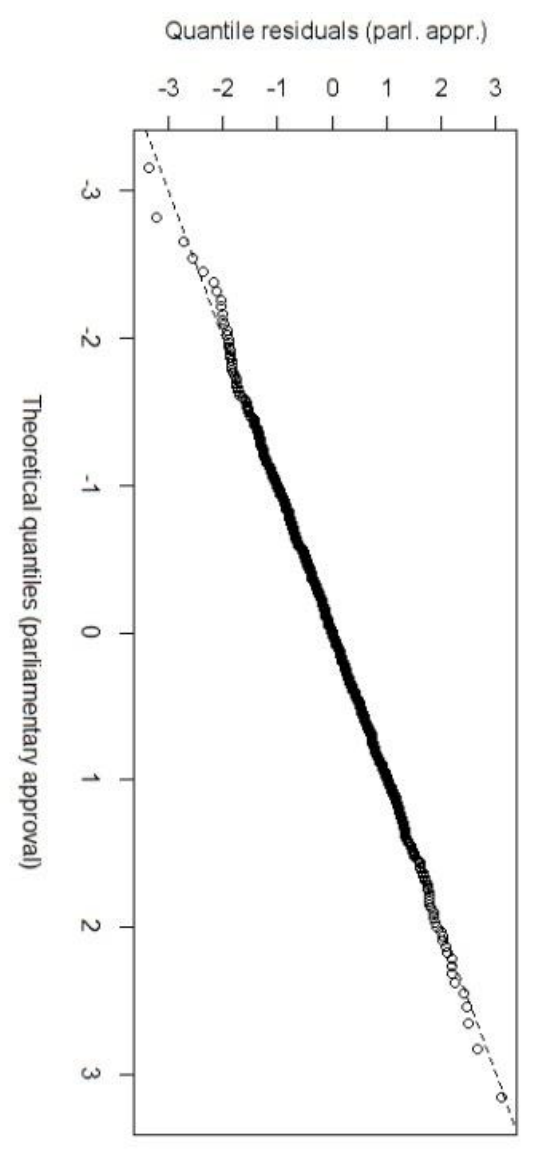

Quartile residuals (gov. ass.)

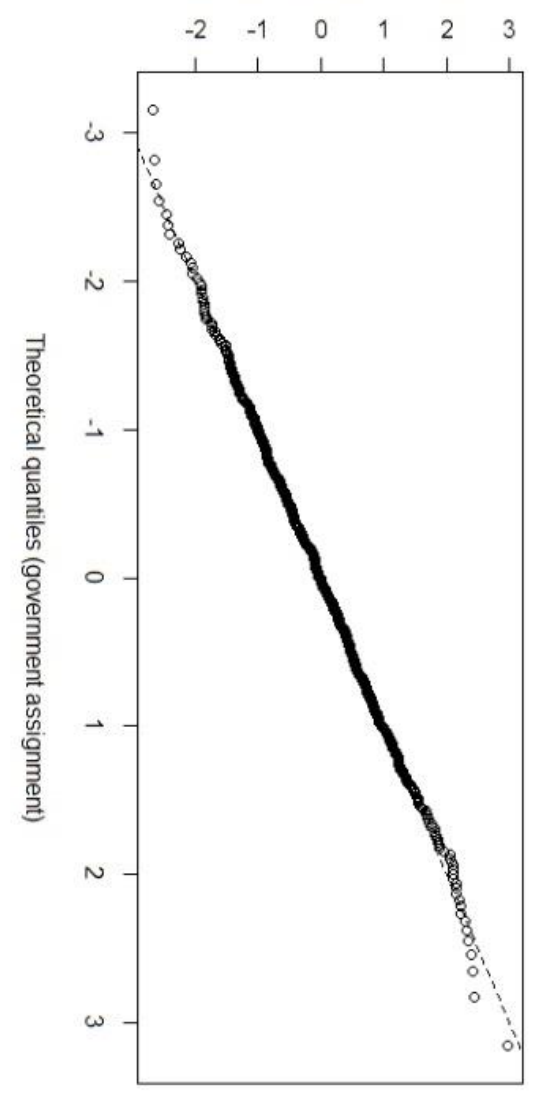

sqrt(Frequency)

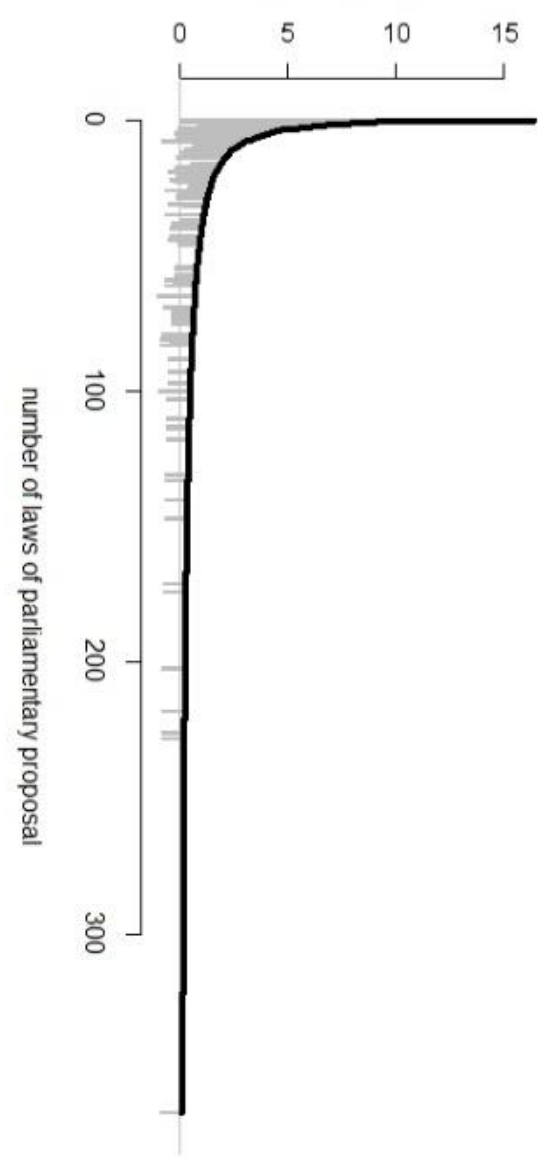

sqrt(Frequency)

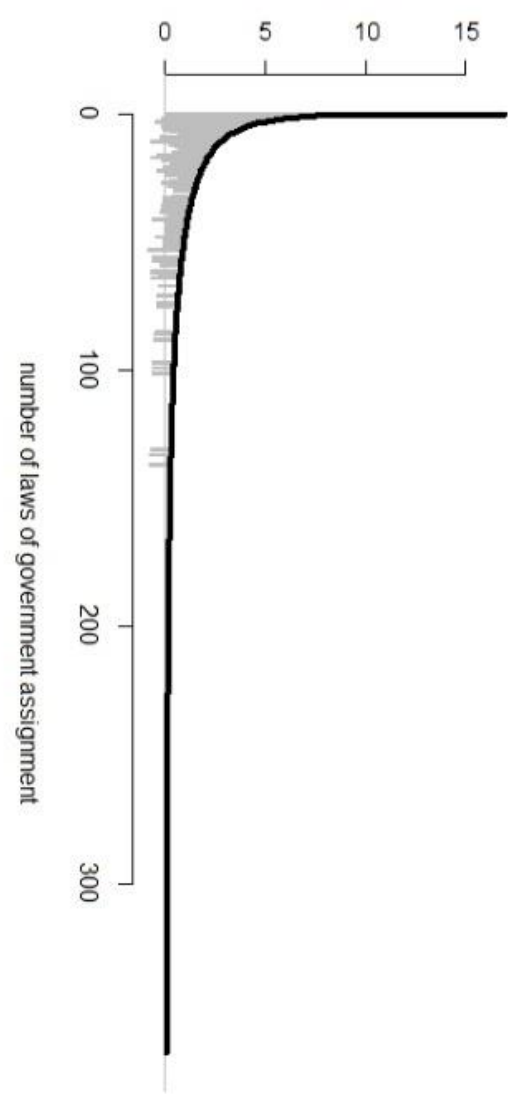

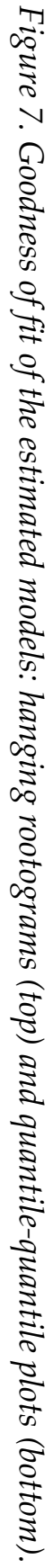

Accepted manuscript 


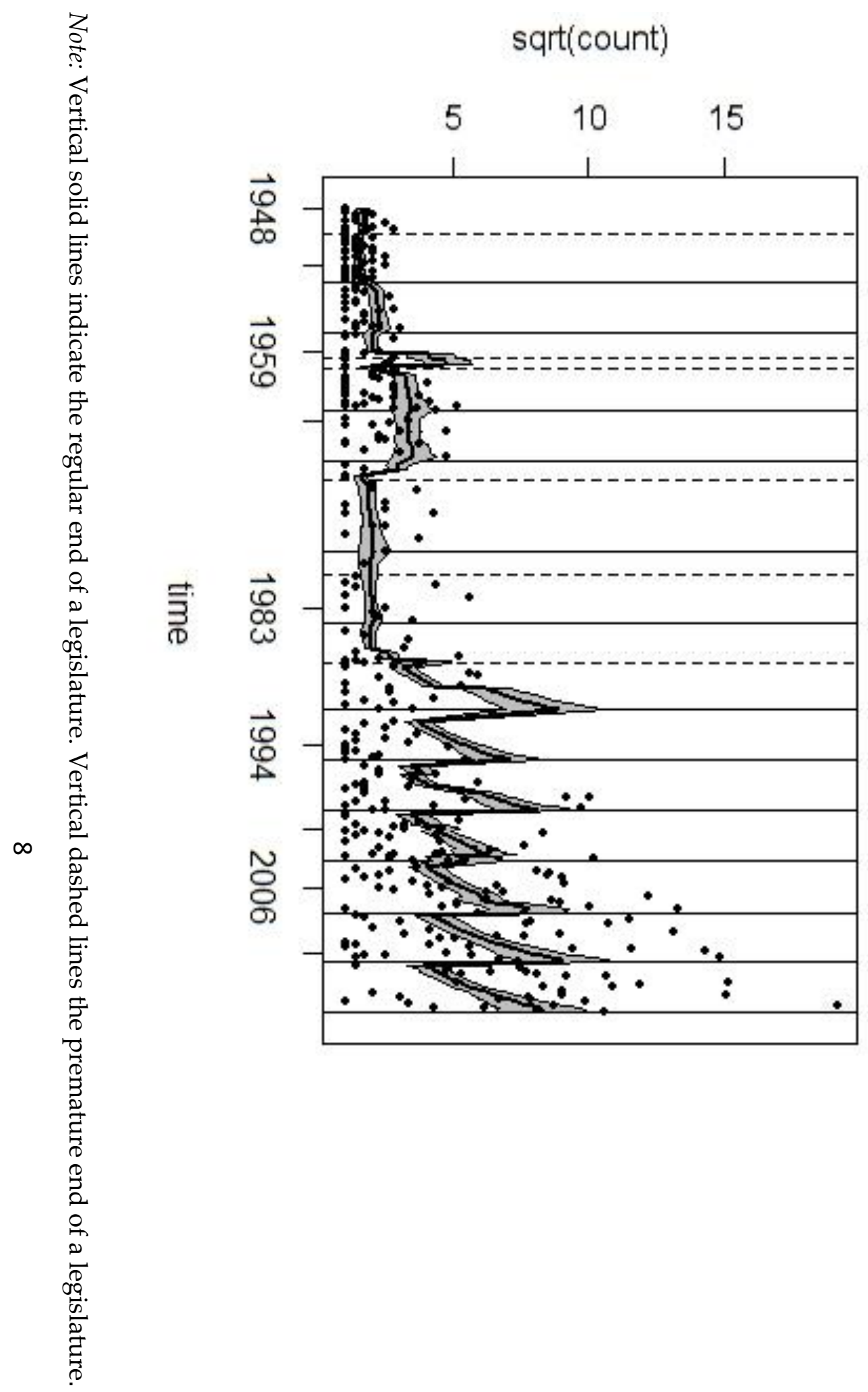




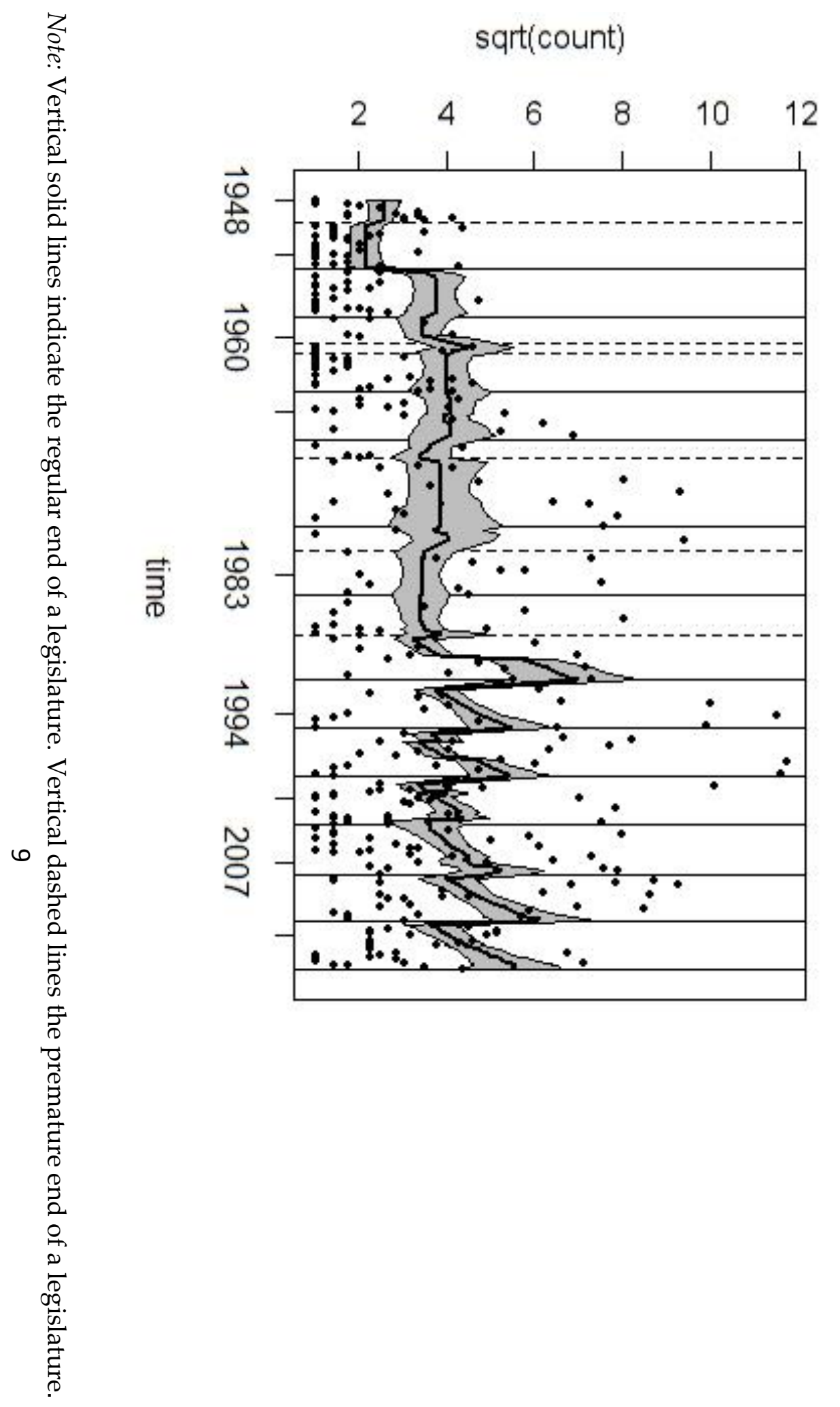




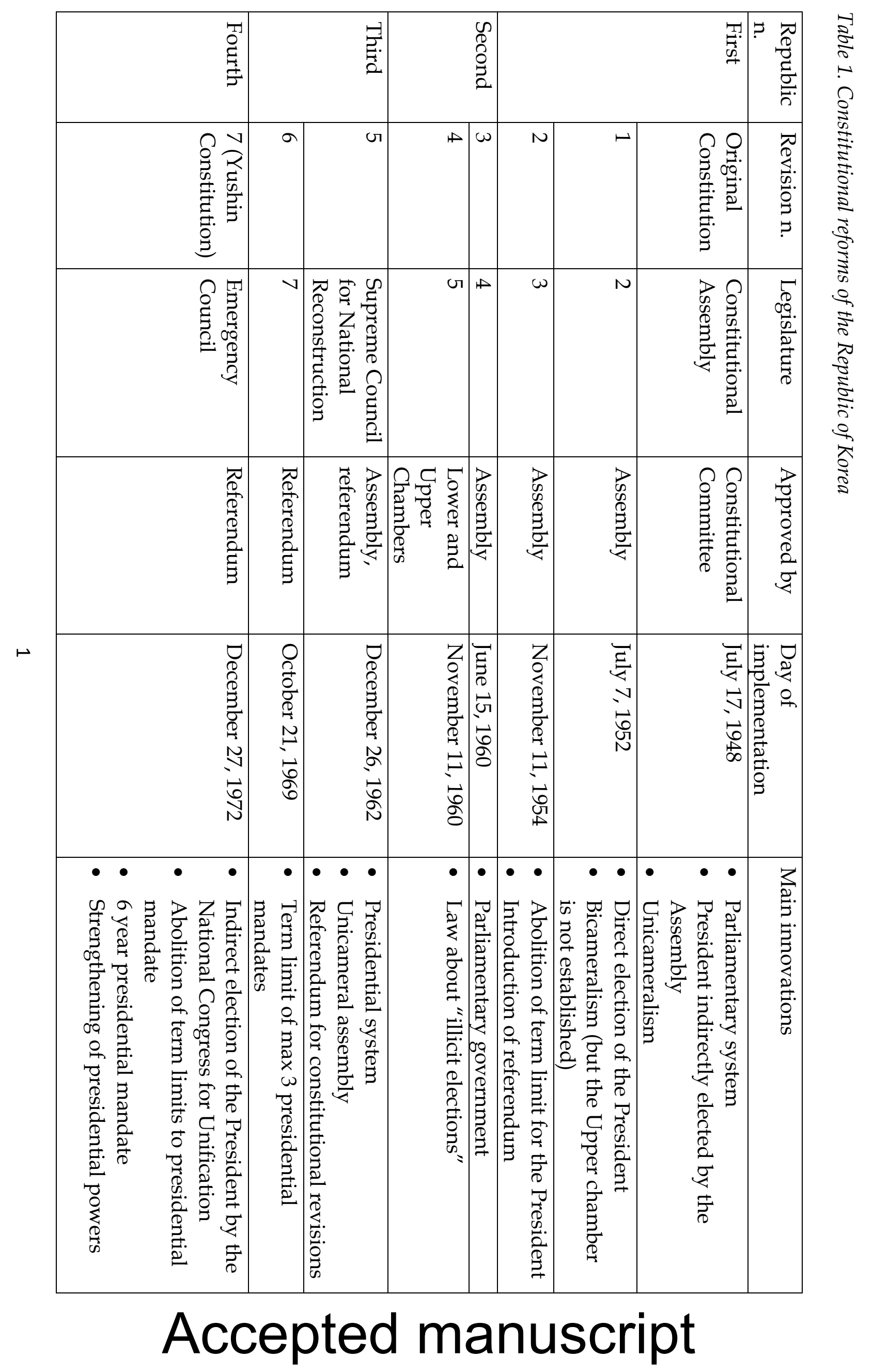




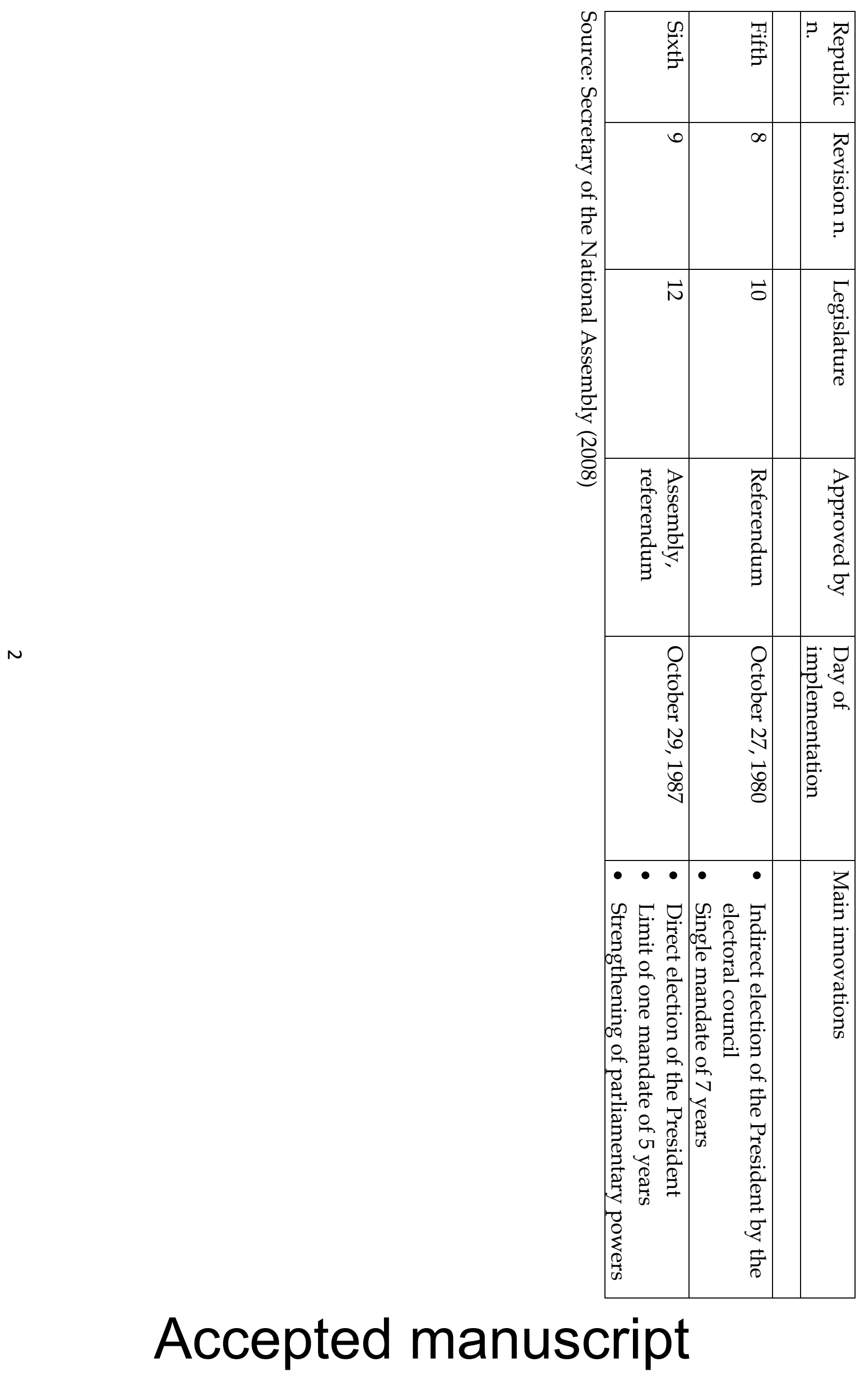


Table 2. Descriptive statistics

\begin{tabular}{|l|l|l|l|l|l|l|}
\hline & Min & $\begin{array}{l}\text { 1st } \\
\text { quartile }\end{array}$ & Median & Mean & $\begin{array}{l}\text { 3rd } \\
\text { quartile }\end{array}$ & Max \\
\hline $\begin{array}{l}\text { Laws of parliamentary } \\
\text { proposal } L^{P P}\end{array}$ & 0 & 0.00 & 1.00 & 11.87 & 6.00 & 366 \\
\hline $\begin{array}{l}\text { Laws of government } \\
\text { assignment } L^{G A}\end{array}$ & 0 & 0.00 & 1.00 & 8.51 & 7.50 & 137 \\
\hline Majority size (\%) $k$ & 11.40 & 47.80 & 53.60 & 51.12 & 61.60 & 75.50 \\
\hline Majority size (\%) $k($ leg. 1-12) & 11.40 & 53.60 & 56.60 & 51.82 & 62.90 & 75.50 \\
\hline Majority size (\%) $k($ leg. 13-19) & 17.20 & 43.10 & 51.20 & 50.26 & 52.70 & 72.90 \\
\hline Legislature duration $t$ & 10.00 & 31.00 & 45.00 & 39.58 & 47.50 & 69.00 \\
\hline Polity IV scores & -9.00 & -4.00 & 3.00 & 1.96 & 8.00 & 8.00 \\
\hline Polity IV scores (leg. 1-12) & -9 & -5 & -4 & -2.50 & 3 & 8 \\
\hline Polity IV scores (leg 13-19) & 6 & 6 & 8 & 7.42 & 8 & 8 \\
\hline
\end{tabular}

\section{Accepted manuscript}


Table 3. Legislatures of the Republic of South Korea (1948-2016)

\begin{tabular}{|l|l|l|l|}
\hline $\begin{array}{l}\text { Legislature } \\
\text { number }\end{array}$ & Republic & Duration & Type of end \\
\hline 1 & First & $1948-1950$ & Premature (outbreak of Korean War) \\
\hline 2 & First & $1950-1954$ & Regular \\
\hline 3 & First & $1954-1958$ & Regular \\
\hline 4 & First & $1958-1960$ & Premature (April revolution) \\
\hline 5 & Second & $1960-1961$ & Premature (Coup d'état of May 1961) \\
\hline 6 & Third & $1963-1967$ & Regular \\
\hline 7 & & $1967-1971$ & Regular \\
\hline 8 & & $1971-1973$ & Premature (Approval of Yushin Constitution) \\
\hline 9 & Fourth & $1973-1978$ & Regular \\
\hline 10 & & $1978-1980$ & Premature (Coup d'état of December 1979) \\
\hline 11 & Fifth & $1981-1985$ & Regular \\
\hline 12 & & $1985-1987$ & Premature (Constitutional reform of 1987) \\
\hline 13 & Sixth & $1988-1992$ & Regular \\
\hline 14 & & $1992-1996$ & Regular \\
\hline 15 & & $1996-2000$ & Regular \\
\hline 16 & & $2000-2004$ & Regular \\
\hline 17 & & $2004-2008$ & Regular \\
\hline 18 & & $2008-2012$ & Regular \\
\hline 19 & & $2012-2016$ & Regular \\
\hline
\end{tabular}


Table 4. Effects on the number of laws of parliamentary proposal and on legislative activity, estimated via a hurdle negative binomial model

\begin{tabular}{|l|l|l|l|}
\hline \multicolumn{5}{|c|}{ Number of approved laws } \\
\hline & Estimated coefficient & Standard error & p-value \\
\hline Intercept & -0.274 & 0.377 & 0.468 \\
\hline$t$ (legislature) & -0.005 & 0.009 & 0.537 \\
\hline$k$ (majority) & 0.026 & 0.006 & 0.000 \\
\hline Polity IV score & 0.146 & 0.025 & 0.000 \\
\hline$\delta \times t$ & 0.033 & 0.011 & 0.004 \\
\hline $\log \left(1 / \sigma^{2}\right)$ & -1.265 & 0.227 & 0.000 \\
\hline & \multicolumn{3}{|c|}{ Legislative activity } \\
\hline \multicolumn{3}{|c|}{0.208} \\
\hline Intercept & Estimated coefficient & Standard error & $\mathrm{p}$-value \\
\hline Sitting days in the month & -0.467 & 0.026 & 0.024 \\
\hline$t$ (session) & 0.018 & 0.008 & 0.002 \\
\hline Pseudo $\mathrm{R}^{2}$ & \multicolumn{3}{|c|}{0.024} \\
\hline N. of counts & \multicolumn{3}{|c|}{} \\
\hline N. of $l$ & \multicolumn{3}{|c|}{6369} \\
\hline
\end{tabular}


Table 5. Effects on the number of laws of government assignment and on legislative activity, estimated via a hurdle negative binomial model

\begin{tabular}{|c|c|c|c|}
\hline \multicolumn{4}{|c|}{ Number of approved laws } \\
\hline & Estimated coefficient & Standard error & p-value \\
\hline Intercept & 0.517 & 0.351 & 0.141 \\
\hline$t$ (legislature) & -0.000 & 0.008 & 0.969 \\
\hline$k$ (majority) & 0.028 & 0.006 & 0.000 \\
\hline Polity IV score & 0.014 & 0.025 & 0.575 \\
\hline$\delta \times t$ & 0.023 & 0.011 & 0.038 \\
\hline $\log \left(1 / \sigma^{2}\right)$ & -1.186 & 0.219 & 0.000 \\
\hline \multicolumn{4}{|l|}{ Assembly activity } \\
\hline & Estimated coefficient & Standard error & p-value \\
\hline Intercept & -0.560 & 0.208 & 0.007 \\
\hline Sitting days in the month & 0.027 & 0.009 & 0.001 \\
\hline$t($ session $)$ & 0.012 & 0.007 & 0.108 \\
\hline Pseudo R ${ }^{2}$ & \multicolumn{3}{|c|}{0.078} \\
\hline N. of counts & \multicolumn{3}{|c|}{631} \\
\hline N. of $l$ & \multicolumn{3}{|c|}{7487} \\
\hline
\end{tabular}


HOW DOES LEGISLATIVE BEHAVIOR CHANGE WHEN THE COUNTRY BECOMES

DEMOCRATIC? THE CASE OF SOUTH KOREA

by

FRANCESCO LAGONA

and

FABIO PADOVANO

\section{STATEMENT ABOUT CONFLICT OF INTERESTS}

The authors hereby declare that neither of them has a conflict of interests of whatsoever nature about the research conducted in this paper 